\title{
Reuse of Single Use Device
}

National Cancer Institute

\section{Source}

National Cancer Institute. Reuse of Single Use Device. NCI Thesaurus. Code C91893.

Problems traced to the use of the device more than once when it is designed for only one use. 